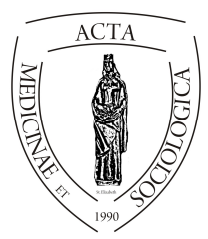

\title{
Az osztálytermi befogadás és kirekesztés mintázatai egy kárpátaljai iskolában
}

\author{
Cséke Katalin \\ Doktorandusz, Debreceni Egyetem Humán Tudományok Doktori Iskola, Neveléstudományi Doktori Program \\ (Debrecen, 4032, Egyetem tér 1.) \\ Tanársegéd, II. Rákóczi Ferenc Kárpátaljai Magyar Főiskola ( Kossuth tér 6, 90202 Beregszász, Kárpátalja , Ukrajna)
}

\begin{tabular}{ll}
\hline \multicolumn{1}{c}{ INFO } & \multicolumn{1}{c}{ ABSTRACT } \\
\hline Katalin Cséke \\
cseke.katalin85@gmail.com & $\begin{array}{l}\text { The patterns of classroom inclusion and exclusion in a } \\
\text { Transcarpathian school. In the recent years, similarly to } \\
\text { Hungary, a variety of integrational activities appeared at the } \\
\text { schools of Subcarpathia as well. The majority of these } \\
\text { integration, } \\
\text { acceptance, } \\
\text { exclusion, } \\
\text { activities are affiliated with religious institutions, some of } \\
\text { them have become a part of the educational system. However, } \\
\text { QSL } \\
\text { there is also an unofficial educational practice, designed by } \\
\text { the teachers, which has been used at the Secondary School of } \\
\text { Nagydobrony for years: the elementary education of the } \\
\text { romani children takes place in a separate building, in a } \\
\text { separate class. During the first four years of education a pa- } \\
\text { rallel, integrational" class is operated for the romani children, } \\
\text { then, in the beginning of the fifth year they are united with the } \\
\text { non-romani children, and they study together up to the } \\
\text { eleventh grade. In my research I am looking for the answer to } \\
\text { the question whether the romani children are able to unite, } \\
\text {,integrate" with the other students, and how they accomplish } \\
\text { it. In my presentation I will show the data that I collected from } \\
\text { students in a Subcarathian settlement with the largest } \\
\text { Hungarian population, in connection with the methodology } \\
\text { and the first database of an international research. In my } \\
\text { analysis, I will examine the climate in the classroom, the } \\
\text { milieu of the school, the relationships in the institution, the } \\
\text { successes and failures. Further dimensions of the research } \\
\text { include the settlement itself, the family background, the } \\
\text { features of the household, religiousness and ethnic identity. } \\
\text { The method of the analysis is a questionnaire based on self- } \\
\text { reporting, which is an integral part of the newly developed } \\
\text { Questionnaire of School Life (QSL). The questionnaire was } \\
\text { filled in by 109 students of the seventh and eighth grade. The } \\
\text { preliminary results of the questionnaire indicate that the } \\
\text { romani children feel a lot better among their romani fellows }\end{array}$ \\
\hline
\end{tabular}


and the integration usually does not happen, not even among the older students. Learning difficulties and failures accompany the children during the years of education. Acceptance in the classroom depends on the school performance. The performance of the romani children gets worse, they begin to miss school more often. The main reasons of this are the family background, the lack of motivation for studying and the differences in the socialization of the students.

Kulcsszavak
integráció,
elfogadás,
kirekesztés,
önértékelés,
QSL

Kulcsszavak integráció, elfogadás, kirekesztés, QSL
Absztrakt: Az utóbbi években Magyarországhoz hasonlóan Kárpátalján is sokféle felzárkóztató tevékenység jelent meg az iskolában. Ezek többsége vallási szervezetekhez köthető, és nagyrészük már az oktatási rendszer részeivé vált. Van azonban egy olyan nem hivatalos, a pedagógusok által kidolgozott oktatási gyakorlat, mely a Nagydobronyi Középiskolában évek óta müködik: a roma gyerekek külön épületben, külön osztályban való elemi oktatása. Az első négy osztályban párhuzamosan működik egy „,felzárkóztató” osztály roma gyerekek számára, majd az ötödik évben betagozódnak a nem roma gyerekek közé, ahol tizenegyedik osztályig együtt folytatják tanulmányaikat. Vizsgálatunkban arra a kérdésre kerestük a választ, hogy belépve a többségi osztályba ezek a gyerekek tudnak-e integrálódni, ,felzárkózni” a többi diákhoz, és hogyan. Egy nemzetközi kutatás módszertanához és első adatbázisához kapcsolódóan gyüjtöttünk új adatokat Kárpátalja legnagyobb magyar lélekszámmal rendelkező településén lévő középiskola tanulói köréből. Elemzésünkben vizsgáljuk az osztálytermi klímát, az iskolai miliőt, iskolai kapcsolatokat, sikereket és kudarcokat. A kutatás további dimenziói a település, a családi háttér, a háztartás jellemzői, a vallásosság, és az etnikai hovatartozás. A vizsgálat módszere önbevalláson alapuló kérdőív, melynek integráns része az újonnan kidolgozott Questionnaire of School Life (QSL). A kérdőívet 109 hetedikes és nyolcadikos diák töltötte ki. A kérdőíves kutatás első eredményei azt mutatják, hogy a roma gyerekek sokkal jobban érzik magukat roma társaik között és nagyon sok esetben felsőbb osztályokban az integrálódás nem is valósul meg. Tanulási nehézségek, ebből adódóan kudarcok kísérik végig tanulmányaik során a gyerekeket. Az osztályon belüli elfogadás pedig függ az iskolai teljesítménytöl. Tanulmányi eredményeik romlanak és gyakori az iskolából való kimaradás is. Az okok között találjuk többek között a hozott családi tőkét, a tanulási motiváció hiányát, szocializációs különbségeket. 


\section{Bevezetés}

Ma Kárpátalján a társadalom, az oktatáspolitika és nem utolsó sorban a szakma döntése, hogy a befogadó vagy a szegregált iskolát részesíti előnyben. Az iskola és környezete értelmezésének alapvető szempontja kell legyen a történelmi idő és a társadalmi tér. Kárpátalján is megtalálható a Ligeti György (2005) által leírt az állampolgári szocializáció szempontjából besorolható iskolatípusok mindegyike, de talán nem a megfelelő arányban. Az első típusba az ún. „,versenyistállóként” müködő iskolák tartoznak, ahol a cél a teljesítmény növelése, a későbbi sikeres felvételi vizsgára való felkészülés. Ezzel ellentétben az elfekvőnek mondható iskolák is jelen vannak. Itt éppen, hogy zajlik valamiféle oktatás. De mind a tanárok, mind a diákok tudják, hogy az itt folyó tanulmányi munka kevés a későbbi munkaerő-piaci elhelyezkedéshez. Végül megemlíthetjük a szabadelvü, vagy újabban alternatív iskolaként jelenlévő intézményeket. Itt különös hangsúlyt kap a tudatos demokratikus nevelés. Ezen intézmények száma csekély a kárpátaljai magyar nyelvü oktatásban, de már jelen vannak. Míg az első típusú oktatási intézményekben nincs idő a nevelésre, a kommunikációra, az egyéni gondolkodás fejlesztésére, mert át kell adni a tananyagot, jegyet kell adni, osztályozni, mérni, addig a harmadik típus iskolái nem is tudnának így müködni hisz a társadalmi integrációhoz nélkülözhetetlen képességek fejlesztése, a felzárkóztatás a fő célkitüzésük. Ezekben az iskolákban hátrányos helyzetüek és középosztálybeliek, romák és nem romák, épek és sajátos nevelési igényü tanulók is megtalálhatók.

A nevelés célja mindig is az volt, hogy a gyereket alkalmassá tegye a sikeres társadalmi beilleszkedésre. Az iskolarendszer, és az oktatáspolitika egy másik cél mentén - szürés és szelektálás - időnként ennek a célnak ellentmond, hisz egyre több gyermek nem tud megfelelni az iskola elvárásainak a családi szociokulturális háttér, a nyelvi szocializáció hiányosságai, esetleg a gyermekben meglévő adottságok, illetve a képességfejlődésében mutatkozó zavarok miatt. Ez utóbbi csoportosításba a testi fogyatékossággal rendelkező tanulók tartoznak, a család szociokulturális mássága alatt általában a roma gyerekek beilleszkedési zavarait értjük (Pető és Nagy 2004). Speciális nevelési szükségletü tanulónak a mai értelmezés szerint azokat a gyerekeket tekintjük, akik testi, érzékszervi vagy értelmi sérülés, illetve részképességzavar miatt nem képesek a hagyományos iskolarendszerben az oktatás-nevelés hagyományos feltételei között a követelményeknek megfelelni (Petö és Nagy 2004:174). Ez a kifejezés azonban kiterjedt azokra a gyerekekre is, akik iskolai követelményeiknek nem tudnak megfelelni a család szociális, kulturális helyzete vagy éppen származásuk miatt. Az e csoportra való fokozottabb odafigyelés miatt vált ismertté a szociális befogadó nevelés (angol nyelvterületen: social inclusion) fogalma és gyakorlata, az inklúzió. Az inklúzió a kirekesztéstől való mentességet kifejező pozitív fogalom (Ferge 2002), mely a sokféleség minden aspektusának felismerését, méltányolását és értékelését igényli. Az inklúzió célja nem a beolvasztás, nem a szokások, hagyományok, kultúra, vallás elfelejtése, hanem ellenkezőleg, a láthatónak maradás, a megkülönböztető tulajdonságok megmaradásának lehetősége. Míg az integráció esetében az a cél, hogy minél több gyermek tanuljon a többségi (általános) iskolában, vagyis a szegregált intézmény helyett egy integráló iskolában, addig az inklúzió esetében az a cél, hogy szinte valamennyi gyermek a lakóhelyéhez közel eső iskolában tanulhasson (Pető és 
Nagy 2004:174). Az inkluzív pedagógia megjelenése tehát az iskolai nevelés új paradigmájaként értelmezhető, melynek eredménye, hogy az iskola alkalmassá válik minden egyes gyermek nevelési szükségletének a kielégítésére (Csányi 2000, Papp 1995).

„Az integrációval az egyéneket be kívánják olvasztani az iskola meglévő struktúráiba, míg az inklúziónál újra átgondolják a tanterv megvalósításának szervezeti kereteit és azokat a feltételeket, amelyekkel valamennyi tanuló haladását biztosítani tudják" (Sebba 1996).

Kutatásunkban arra vállalkoztunk, hogy feltérképezzük egy kárpátaljai középiskola befogadással kapcsolatos lehetőségeit és feltételeit. Ennek megfelelően kérdőívet töltettünk ki az iskola tanulóival $(\mathrm{N}=109)$. A kérdöívek egy nemzetközi kutatás részét képezik, melynek tárgya az iskolai inklúzió (Fónai és Hüse 2018, Fónai et al. in press). A kutatás 2015-ben vette kezdetét, melynek keretében csaknem hétszáz tanulót kérdeztünk meg és 23 tanárt (fókuszcsoportos interjúval) Magyarországon, Lengyelországban és Ukrajnában. Tanulmányunkban az ukrajnai kutatás első eredményeit elemezzük.

\section{A kutatás módszere}

A kutatás módszere kérdőíves adatfelvétel volt. A kérdőív Farnicka és munkatársai által az iskolai marginalizáció mérésére kidolgozott új eszköz, az „Iskolai életminőség kérdőív" (Questionnaire of School Life, QSL) (Farnicka et al. 2014), melynek használatáról már olvashattunk egyes iskolákra, vagy akár osztályokra fókuszáló, főként pedagógiai, szociális és prevenciós programok és stratégiák megalkotásánál (Hüse 2015, Balogh és Hüse 2017). A QSL három dimenziója az önértékelés, az elfogadás/támogatás és a kirekesztés megélése.

\section{Háttérváltozók és összefüggések}

Kérdőívünk első részében az elemzést, valamint a folyamatok megértését segítő háttérváltozókra kérdeztünk rá. A kapott eredményeket különösebb értelmezés nélkül, csakis az adatok szintjén mutatjuk be. A háttérváltozók a következők: nem, életkor, osztály.

A válaszadók 62\%-a lány, 36\%-a fiú, két tanuló nem válaszolt a kérdésre. 12 (29\%), 13 (45\%), 14 (26\%) évesek és hetedik (50,5\%) ill. nyolcadik (49,5\%) osztályba járnak.

A település esetünkben Kárpátalja legnépesebb számú magyar falva, Nagydobrony, amely a megyeszékhelytől 42 km-re fekszik. A 2001-es népszámlálási adatok szerint az állandó lakosság 5607 fö, ebből 400 fő (7,9\%) cigány nemzetiségü (Braun, Csernicskó és Molnár 2010:47), a falu lakossága magyar anyanyelvü. A Nagydobronyi Középiskola huszonkét osztállyal müködik. Az elemi osztályok roma tanulói a református egyház által müködtetett és finanszírozott épületben külön tanulnak, majd ötödik osztályban betagozódnak a középiskola megfelelő osztályába és együtt tanulnak tovább a nem roma gyerekekkel. 
Fontos tényező a szülők iskolai végzettsége. Hazai és külföldi kutatások sokasága igazolja a szülő iskolai végzettsége és a gyerek iskolai előmenetele közötti kapcsolatot. Ezen vizsgálatok alapján elmondható, hogy a családi háttér szerepe - ezen belül is elsősorban a szülők iskolai végzettsége és az általuk közvetített kultúra - alapvetően befolyásolja a gyermekek további sorsát. A tanulási motívum fejlettsége is részben magyarázható a szülők iskolai végzettségével, munkanélküliségével (Fejes és Józsa, 2005). Vizsgálatunkban a szülők iskolai végzettségét tekintve a többségük befejezett általános iskolai végzettséggel rendelkezik (1. táblázat).

\begin{tabular}{|l|c|c|}
\hline & Apa & Anya \\
\hline Kevesebb, mint 8 osztály & 9,2 & 11 \\
\hline Befejezett általános & 22 & 22,9 \\
\hline Szakmunkásvizsga (érettségi nélkül) & 4,6 & 9 \\
\hline Szakközépiskola & 20,2 & 13,8 \\
\hline Gimnázium & 6,4 & 13,8 \\
\hline Technikum & 5,5 & 1,8 \\
\hline Főiskola & 9,2 & 11 \\
\hline Egyetem & 8,3 & 11 \\
\hline Nem tudja & 13,8 & 11,0 \\
\hline
\end{tabular}

Forrás: saját adatfelvétel, 2017

1. táblázat. A szülők iskolai végzettsége (\%).

A tanuláshoz kapott segítségnyújtásra vonatkozóan arra kerestük a választ, hogy a gyerekek kitől számíthatnak támogatásra a tanulás terén a környezetükben. A szülőktől, nagyszülőktől kapott segítségnyújtás a leggyakoribb, míg az iskolán kívüli segítők (magántanár, logopédus, pszichológus) szerepe a legkisebb (1. ábra). Ez utóbbinak az egyik oka lehet, hogy nagyon kevés a magyarul (is) beszélő szakember jelenléte az adott szakmákban, így a magyar anyanyelvü gyerekek szülei sokszor nem tudnak segítséget kérni gyermekeiknek. A szakirodalom szerint a sikeres integráló nevelésben objektív és szubjektív feltételek játszanak szerepet. Ezek személyi, tárgyi és szakmai feltételeket jelentenek. Az objektív tényezők között szerepel a törvényi és pénzügyi háttér, a speciális taneszközök, gyógyászati segédeszközök, az osztály létszáma, összetétele, az épület hozzáférhetősége, a tanterem adottságai, a segítő szolgáltatások és személyek biztosítása, a korrekt diagnózis, megfelelő iskolai követelmények és értékelési rendszer. Az integráció szubjektív tényezői a gyógypedagógus és a fogadó pedagógus kapcsolata, az osztálytársak, a család pozitív és támogató hozzáállása (Csányi 2000). 


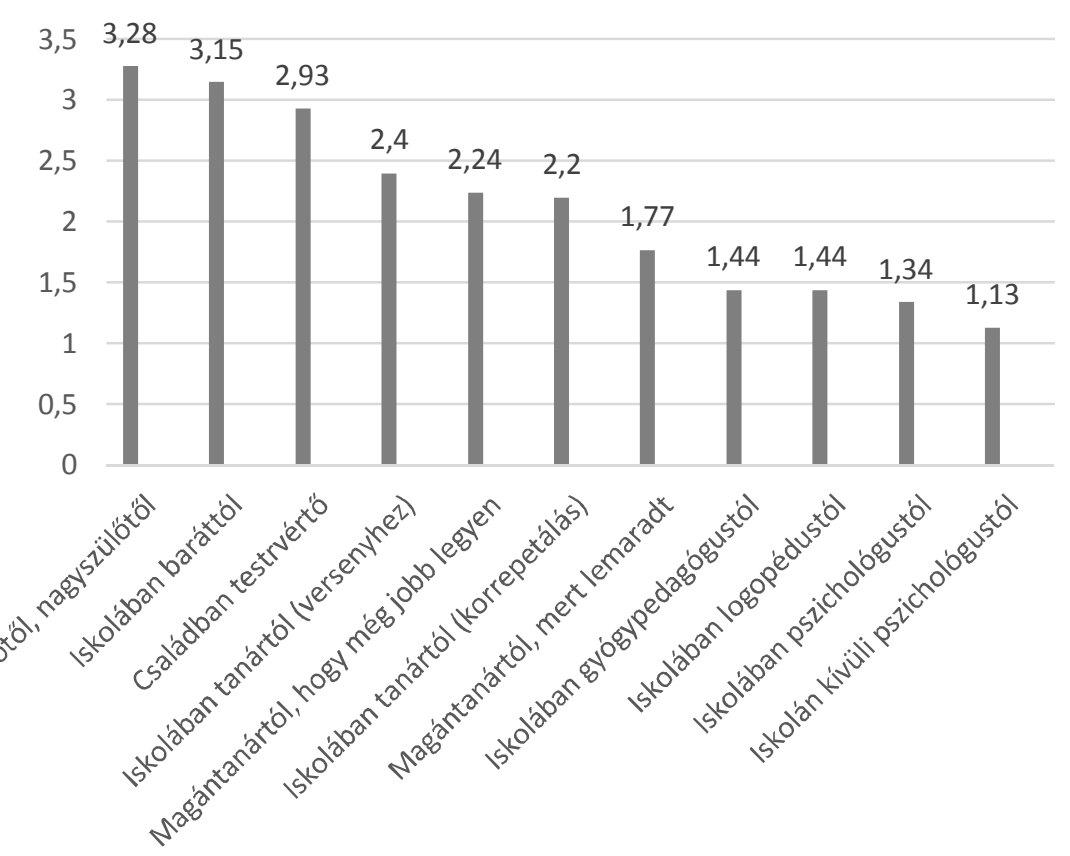

Forrás: saját szerkesztés, 2017

1. ábra. Milyen gyakran kap segítséget a tanuláshoz (ötfokozatú skála).

A nagyon jó tanulmányi eredménnyel jellemezhetők kapnak a leggyakrabban segítséget a barátaiktól ( $\mathrm{p}=0,03)$ (4 pont), majd pedig azok, akik átlagos tanulók $(3,22)$, öket követik az ennél rosszabb tanulók $(3,13)$, s végül a legritkábban a jó tanulók $(2,79$ pont). Nem meglepő módon szintén a nagyon jó és jó tanulmányi eredménnyel jellemezhető diákok kapnak a leggyakrabban segítséget a tanároktól $(\mathrm{p}=0,02)$ a versenyekhez való felkészüléshez ( 3,36 és 2,71 pont), s legritkábban az átlagosak (1,8 pont).

\section{Vallásosság}

Az ezredforduló óta egyre több magyarországi kutatás számol be arról, hogy a hátrányos helyzetböl kiemelkedő fiatalok életében a vallásosságnak döntő szerepe lehet (Hüse 2017). Egy gyermeknevelési eredményességet felmutató romák körében végzett esettanulmány elsősorban a társadalom más rétegei felé mutató kapcsolatok információ- és kultúraközvetítő erejével magyarázta a templomba járás pozitív szerepét a romák körében (Pusztai és Torkos 2001).

Felmérésünk eredményeként elmondható, hogy a megkérdezett tanulók jelentős része hisz Isten létezésében és rendszeresen imádkozik, így esetünkben is kimutatható a kapcsolat (2. ábra). A roma és nem roma tanulók közötti különbség nem mutat szignifikáns eredményt $(\mathrm{p}=0,93)$. 
Hiszem, hogy Isten létezik

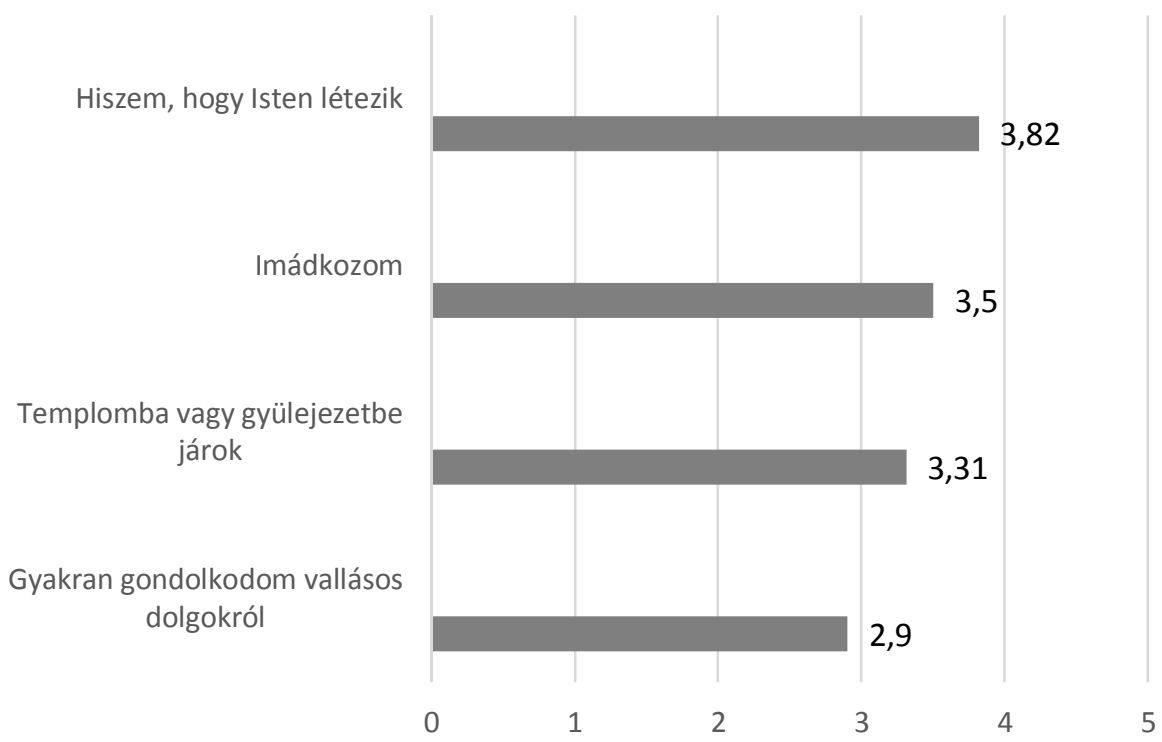

Forrás: saját szerkesztés, 2017

2. ábra. Mennyire jellemzők a tanulókra (négy fokozatú skálán).

Számos tanulmány mutat pozitív kapcsolatot az önértékelés és a vallásosság között. Esetünkben a szakirodalomnak ellentmondva nem mutatható ki kapcsolat az önértékelés és a vallás között.

Szignifikánsan gyakrabban imádkoznak a jó és átlagnál rosszabb tanulók (3,68 és 3,63 pont), a legritkábban pedig a nagyon jó tanulók (3,47 pont). A jó és az átlagos tanulók érzik leginkább, hogy Isten része az életüknek és a nagyon jó tanulók a legkevésbé (2,42 pont) (2. táblázat).

A lányok gyakrabban járnak templomba, mint a fiúk (2,50 és 3,11 pont), viszont a fiúk inkább érzik, hogy Isten része az életüknek (3,65 és 3,22 pont).

\begin{tabular}{|c|c|c|c|c|}
\hline \multirow{2}{*}{ Jegyei alapján } & \multicolumn{2}{|c|}{ imádkozik $^{1}$} & \multicolumn{2}{c|}{ Isten része az életének } \\
\cline { 2 - 5 } & Átlag & $\mathrm{N}$ & Átlag & $\mathrm{N}$ \\
\hline átlagnál rosszabb & 3,63 & 8 & 3,25 & 8 \\
\hline átlag & 3,47 & 40 & 3,43 & 40 \\
\hline jó & 3,68 & 41 & 3,57 & 42 \\
\hline nagyon jó & 2,83 & 12 & 2,42 & 12 \\
\hline Összesen & 3,50 & 101 & 3,35 & 102 \\
\hline
\end{tabular}

$\mathrm{p}^{1}=0,013 ; \mathrm{p}^{2}=0,001$;

Forrás: saját adatfelvétel, 2017

2. táblázat. Az iskolai teljesítmény és a vallásosság kapcsolata. 


\section{Önértékelés}

Már az iskolába lépés előtt a gyerekek kialakult énképpel rendelkeznek a szülők és a közvetlen környezet visszajelzései alapján, azonban a tényleges teljesítményre vonatkozó értékelés az iskolás korban alakul ki. Az iskoláskor során kezdik el a gyerekek az ént kortársaikhoz viszonyítva meghatározni. Az énképpel szorosan összefügg az önértékelés, melyet a kognitív készségek, a testi készségek, a kortársak közti elfogadottság és az anyai elfogadottság alkotják. Az önértékelés kulcsa az az érzés, hogy önmaga és környezete szabályozása révén az ember bizonyos mértékig képes befolyásolni saját jövőjét. Ennek a befolyásolásnak vannak korlátai, s ezek a korlátok ismerete határozza meg, hogy a gyermek pozitív vagy negatív önképpel rendelkezik (Cole és Cole 1997).

Az énkép és az iskolai sikeresség közötti kapcsolatot számos vizsgálat igazolta már. A magas önértékelésü gyerekek nagyobb önbizalommal rendelkeznek, elégedettebbek az életükkel, ambiciózusabbak, és gyakrabban töltenek be vezető pozíciót a csoportban. Ezzel szemben az alacsony önértékelésủ gyereknél gyakrabban tapasztalhatunk rosszabb iskolai teljesítményt, kapcsolatteremtési gondokat, szociális izolációt és negatív érzelmi megnyilvánulásokat, mint például szomorúság, depresszió (Bárányné, Horvát és Ráczné 2013).

A pozitív énképpel rendelkező tanulók iskolai környezetben kitartóbbak, időbeosztási stratégiát választanak, míg a negatív énképpel rendelkező diákoknál gyakran megfigyelhetünk nem célirányos viselkedést, bámészkodást, időhúzást, a feladatmegoldástól eltérítő magatartást. Egy 4 éves longitudinális vizsgálat eredményei kimutatták (Bachman 1977 idézi Orosz és Szitó 1999), hogy 250 szakközépiskolából lemorzsolódott diák esetén negatív énképet tudtak azonosítani, mely eredményezhette a kimaradást. Megfigyelhető volt, hogy a lemorzsolódott diákok több mint a felénél a várható kudarcoktól való menekülésként értelmezték az iskolából való kimaradást. A jól teljesítő tanulók nemcsak pozitív énképpel rendelkeznek, hanem ennek következtében a családon belüli és a kortárscsoporton belüli pozíciójuk is jobb. „Ez viszont növeli a tanulók iskolai feladatok iránti motivációját, így az énkép a motiváción keresztül végül is az iskolai teljesítmény előrejelzője lesz." (Kőrössy 1997:9) Minél jobb jegyekkel rendelkezik a tanuló, annál magasabb az önértékelése. Felmérésünkben a siker és az önértékelés is kapcsolatot mutat, minél sikeresebb a tanuló az iskolai életben, annál magasabb az önértékelése (a sikert elérők esetében 3,00, sikert nem elérők esetében 2,61 az önértékelés átlag pontja).

Az önértékelésben nagyon jó tanulók érték el a legmagasabb pontszámot $(3,50), \mathrm{s}$ jól látható, hogy minél jobb a tanuló tanulmányi eredménye, annál jobbnak értékeli önmagát, a legalacsonyabban a rossz tanulók $(2,08)$ (3. táblázat). 


\begin{tabular}{|l|c|}
\hline \multicolumn{1}{|c|}{ jegyei alapján } & önértékelés \\
\hline átlagnál rosszabb & 2,08 \\
\hline átlag & 2,61 \\
\hline jó & 2,99 \\
\hline nagyon jó & 3,50 \\
\hline Total & 2,81 \\
\hline $\mathrm{p}=0,00 ;$
\end{tabular}

Forrás: saját adatfelvétel, 2017

3. táblázat. Az iskolai teljesítmény és az önértékelés kapcsolata (átlag pontokban kifejezve).

Az iskolai énkép alakulásában szerepet játszik még a tanári értékelés is. Az iskolai munka során nagyon lényeges, hogy a tanárok minél komplexebb gondolkodásúak legyenek, hiszen ezzel tudják elösegíteni, hogy a diákok énképe is gazdag legyen (Szabó 2003).

A kutatások hangsúlyozzák, hogy az iskolai énképet mindig egy viszonyítási keretben érdemes értelmezni. A Nagy hal a kis tóban effektus miatt elővételezhető, hogy két azonos képességü gyermek közül alacsonyabb lesz az énkép egy magasabb követelményeket támasztó iskolában, mert az énkép viszonyítási kerete az a közösség, amibe éppen beletartozik (Strein 1993 idézi Bárányné, Horvát és Ráczné 2013).

Neményi Mária (2007) egy korábbi kutatásában arra kereste a választ, hogy menynyire befolyásolja az etnikai hovatartozás a tanulók énképét, önbecsülését és iskolai teljesítményét. Kutatása eredményeképp megállapította, hogy a tanulók nagy része fenyegetettségként éli meg cigányságát. A sztereotípiák óhatatlanul beépülnek a gyerekek identitásába, és a gyerekek személyiségének és közvetlen környezetének függvényében fejtik ki hatásukat. Jelen dolgozat eredményeként kimondhatjuk, hogy az általunk vizsgált kárpátaljai diákok körében is alacsonyabb az önértékelés a cigány tanulóknál a többségi, nem cigány tanulók önbecsüléséhez képest és különbséget találunk a nemek és az elfogadás összefüggése tekintetében is: a fiúk több elfogadást kapnak, mint a lányok.

\section{Sikerek, kudarcok}

Az iskolai siker haladást, sikertelenség pedig a tanulásban való lemaradást jelenti esetünkben. A fiúk szignifikánsan magasabbra értékelték azt, hogy mennyire boldog a gyerekkoruk. A válaszadók több mint fele nagyon boldognak érzi magát és nem fordult elő „nagyon boldogtalan” válasz. A nagyon jó és jó tanulók körében többen vannak azok, akik sikert értek el, s a legkisebb az arány az átlagos tanulóknál (4. táblázat). Elmondható, hogy a tanulmányi eredményeket részben a tanulók hozzáállása határozza meg (akik több időt fordítanak a tanulásra és többet olvasnak, azok sikeresebbek), 


\begin{tabular}{|c|c|c|c|}
\hline \multirow{2}{*}{ jegyei alapján } & \multicolumn{2}{|c|}{ siker } & \multirow{2}{*}{ Összesen } \\
\cline { 2 - 4 } & igen & nem & 8 \\
\hline \multirow{2}{*}{ átlagnál rosszabb } & 3 & 5 & $100,0 \%$ \\
\cline { 2 - 4 } & $37,5 \%$ & $62,5 \%$ & 45 \\
\hline \multirow{2}{*}{ átlag } & 15 & 30 & $100,0 \%$ \\
\cline { 2 - 4 } & $33,3 \%$ & $66,7 \%$ & 42 \\
\hline \multirow{2}{*}{ jó } & 28 & 14 & $100,0 \%$ \\
\hline \multirow{2}{*}{ nagyon jó } & $66,7 \%$ & $33,3 \%$ & 12 \\
\hline \multirow{2}{*}{ Összesen } & 10 & 2 & $100,0 \%$ \\
\hline & $83,3 \%$ & $16,7 \%$ & 107 \\
\hline & 56 & 51 & $100,0 \%$ \\
\hline
\end{tabular}

$\mathrm{p}=0,00$;

Forrás: saját adatfelvétel, 2017

4. táblázat: A tanulmányi eredmények és a siker kapcsolata

Visszatérve Neményi Mária kutatására (2007), kifejti, hogy a sikeresség és az osztályon belüli roma tanulók aránya között fennálló negatív viszony nem vezethető vissza semmiféle etnikai sajátosságokra, pusztán az iskolai szegregálódás intézményi szintjén jelentkező folyamatának a következménye. Esetünkben a roma és nem roma tanulók és a sikeresség kapcsolatában meglepő eredmény született, a roma tanulók (15 fö) picit több esetben értek el sikereket, mint a nem roma társaik. Bár a nagyon kicsi előfordulás miatt hosszú távú következtetéseket ezekből az eredményekből nem vonhatunk le.

Azoknak a fiataloknak, akik sikeresek (sikert értek el), magasabb az önértékelése, mint a sikert nem érők esetében ( 3 és 2,61 pont) (5. táblázat).

\begin{tabular}{|c|c|c|c|c|c|c|}
\hline \multirow{2}{*}{ siker } & \multicolumn{2}{|c|}{ önértékelés } & \multicolumn{2}{c|}{ elfogadás } & \multicolumn{2}{c|}{ kirekesztés } \\
\cline { 2 - 7 } & Átlag & $\mathrm{N}$ & Átlag & $\mathrm{N}$ & Átlag & $\mathrm{N}$ \\
\hline igen & 3,00 & 54 & 3,96 & 56 & 1,89 & 57 \\
\hline nem & 2,61 & 51 & 3,78 & 51 & 1,71 & 52 \\
\hline Összesen & 2,81 & 105 & 3,87 & 107 & 1,81 & 109 \\
\hline
\end{tabular}

$\mathrm{p}=0,00$;

Forrás: saját adatfelvétel, 2017

5. táblázat: Az önértékelés, elfogadás, kirekesztés és a siker kapcsolata

A környezettől kapott segítségnyújtás is befolyásolja az önértékelést illetve az elfogadást. Az elfogadásban a legmagasabb értékeket azok érték el, akik rendszeresen vagy gyakran kapnak segítséget valamelyik barátjuktól, a legalacsonyabbat az, aki néha (3,68 pont). Azoknak a gyerekeknek, akik ritkán vagy gyakran kapnak segítséget testvérüktől a legmagasabb az önértékelésük, a legalacsonyabb pedig annak, aki rendszeresen kap segítséget a testvérétől (2,54 pont). Minél több segítséget kap egy gyerek olyan tanártól, aki korrepetálja őket, annál nagyobb az önbizalma (kivéve a rendszeresen kategóriában, ami nem meglepő, hisz csak 8-an vannak): a legmagasabb azoknak, akik gyakran kapnak segítséget ilyen tanártól $(3,60)$, és a legalacsonyabb a rendszeresen segítséget kapóknál $(2,17)$. 
A befogadó, inkluzív nevelés keretein belül a pedagógus együttmüködő, segítő partnere a gyógypedagógus, logopédus, iskolapszichológus, optimális esetben akár egy tanítási órán belül is. A vizsgálatunk középpontjában lévő középiskola tanulói között voltak, akik gyógypedagógushoz fordultak segítségért, így kimutatható lett az az eredmény, hogy minél többet fordul gyógypedagógushoz/kap segítséget, annál kisebb a tanuló önbizalma. Minél többet fordul a gyógypedagógushoz, annál elfogadóbb, kivéve a „rendszeresen” kategóriában lévők, ők érték el a legalacsonyabb pontszámot $(3,07)$. Minél gyakrabban kap segítséget logopédustól annál inkább elfogadóbb, kivéve a gyakran kategóriába tartozók: ők a legkevésbé (2,73, de csak hárman vannak). Akik soha nem kapnak segítséget iskolapszichológustól, azok a leginkább elfogadóbbak $(3,97)$, majd nagyjából egyenletesen csökken, és akik gyakran járnak ők érték él a legalacsonyabb pontszámot $(3,30)$. A ritkán járók érték el a legmagasabb pontszámot a kirekesztésben, rájuk jellemző a leginkább, majd a gyakoriság növekedésével csökkennek a pontszámok, legalacsonyabb a gyakran iskolapszichológushoz járók körében $(1,44)$. A gyakran pszichológushoz fordulók érték el a legmagasabb pontszámot az önértékelésben és a kirekesztésben (3, de ez mindössze 1 föt jelent, tehát az eredmény torzít), a legalacsonyabbat pedig mindkét esetben a pszichológushoz ritkán fordulók érték el. A ritkán és soha magántanárhoz nem járók érték el legmagasabb pontszámot átlagosan az elfogadásban $(4,04$ és 3,91) és a rendszeresen járók pedig a legalacsonabbat (3,27 pont). Összességében elmondhatjuk, hogy azok a tanulók, akik eddigi iskolai éveik alatt gyógypedagógushoz és logopédushoz fordultak segítségért nagyobb elfogadással rendelkeznek társaik iránt, vagyis a segítő szerep pozitív hatást gyakorolt rájuk. Azonban azok a diákok, akik valamilyen testi vagy szellemi fogyatékosságuk miatt gyógypedagógushoz fordultak kisebb önbizalommal rendelkeznek.

\section{Összefoglalás}

Napjainkban egyre többször fedezhetjük fel, hogy egy-egy gyermek különbözik a többiektől. Ennek a különbözőségnek a hátterében állhat testi vagy szellemi fogyatékosság, de az okok között találjuk többek között a hozott családi kulturális tőkét, a tanulási motiváció hiányát, és a szocializációs különbségeket.

A társadalmi kirekesztés csökkentése és a társadalmi integráció az elmúlt évek oktatáspolitikájának kiemelt területe volt. Napjainkban a pedagógiai munka egyik fő feladata az integráció sikeres megvalósítása. Tanulmányunk témája az osztálytermi befogadás és kirekesztés mintázatai, mindez egy kárpátaljai középiskolában. Ennek megfelelően kérdőívet töltettünk ki az iskola tanulóival $(\mathrm{N}=109)$. A kérdőívek egy nemzetközi kutatás részét képezik, melynek tárgya az iskolai inklúzió.

A kárpátaljai kérdőíves kutatás első eredményei azt mutatják, hogy a roma gyerekek jól érzik magukat roma társaik között, de maga az integráció nem valósul meg (különösen, hogy az első években külön iskolákba járnak a roma tanulók). Tanulási nehézségek, ebből adódóan kudarcok kísérik tanulmányaik során e gyerekeket. Az osztályon belüli elfogadás pedig jelentősen függ az iskolai teljesítménytől, a tanulmányi eredményeket főként a tanulók hozzáállása határozza meg (akik több időt fordítanak a tanulásra és többet olvasnak, azok sikeresebbek). 
Ez a vizsgálat egy nagyobb kutatás előfutára, melyben további céljaink között szerepel egy nagyobb mintán való elemzés. Az első eredmények alapján elmondható, hogy a QSL dimenziói igen érzékenyen reagálnak több olyan háttérváltozóra a kárpátaljai tanulók körében is, amely a tapasztalatok és a szakirodalom szerint összefüggésbe hozhatók az iskolai sikerességgel. A QSL egyszerü, teszt-jelleggel felvehető kérdőív, amely valószínüleg alkalmas az iskolai sikerek bejóslására. Az iskolai légkör kapcsán további elemzéseket folytatunk.

\section{Felhasznált irodalom}

1. Balogh E., Hüse L. (2017): Az iskolai közérzet és a rizikómagatartás egyes aspektusainak összefüggései. In: Fábián G., Szoboszlai K., Hüse L. [szerk.]: A társadalmi periférián élő gyermekek és fiatalok rizikómagatartásának háttere. Periféria Egyesület, Nyíregyháza. 91-112.

2. Bárányné Jámbori Sz., Horvát-Militityi T., Ráczné Török E. (2013): Tanulók és tanulócsoportok megismerése - kiemelt figyelmet igénylö tanulók. „Mentor(h)áló 2.0 Program", TÁMOP-4.1.2.B.2-13/1-2013-0008 projekt

3. Barnucz N., Fónai M. (2015). School inclusion and exclusion: experiences of empirical researches, Lecture during Teacher Education in Central and Eastern Europe Conference, 18-21 Juni, Debrecen, Hungary.

4. Braun L., Csernicskó I., Molnár J. (2010): Magyar anyanyelvü cigányok/romák Kárpátalján. Ungvár. PoliPrint Kft.

5. Cole, M., Cole, S. R. (1997): Fejlődéslélektan, Osiris Kiadó, Budapest.

6. Csányi Y. (2000): A speciális nevelési szükségletű gyermekek és fiatalok integrált nevelése-oktatása. In Illyés Sándor (szerk.): Gyógypedagógiai alapismeretek. ELTE BGGYFK, Budapest, 377-409. o.

7. Farnicka M., Liberska H., Kosiková V., Lovasová V., Freundenreich D. (2014): A New Tool in the Fight against Social Exclusion: The Questionnaire of School Life (QSL). In: Hanna Liberska and Marzanna Farnicka (ed): A Child of Many Worlds: Focus on the Ethnic Minority Problem. Frankfurt: Peter Lang Verlag, 177-192.

8. Fejes József Balázs, Józsa Krisztián (2005): A tanulási motiváció jellegzetességei hátrányos helyzetü tanulók körében. Magyar Pedagógia, 2. 185-205.

9. Ferge Zs. (2002): Kétsebességü Magyarország, http://3sz.hu/sites/default/files/ uploaded/ ferge_zsuzsa_ ketsebessegu_ magyarorszag.pdf (Utolsó látogatás: 2017. május 20.)

10. Fónai M., Hüse L. (2018): Roma tanulók és az iskola: befogadás és kirekesztés. In. Endrődy-Nagy O., Fehérvári A. [szerk.]: Innováció, kutatás, pedagógusok. HERA Év-könyvek V. Magyar Nevelés- és Oktatáskutatók Egyesülete, Budapest. 600-611.

11. Fónai M., Hüse L. Balogh E., Toldi A. (in press): School integration, inclusion and exclusion: ex-periences of empirical researches. In. Bálint P., Biczó G. [szerk.] Studia Cingarorum. Debreceni Egyetem Felnőttképzési Kar, Hajdúböszörmény. 
12. Hüse L. (2015): Roma tanulók iskolai attitűdjeit befolyásoló tényezők. Evangélikus Roma Szakkollégium Nyíregyháza.

13. Hüse L. (2017): Vallásosság, vallásos kapcsolatok, és ezek összefüggései a rizikómagatartással. In: Fábián G., Szoboszlai K., Hüse L. [szerk.]: A társadalmi periférián élő gyermekek és fiatalok rizikómagatartásának háttere. Periféria Egyesület, Nyíregyháza. 127-135.

14. Körössy J. (1997): Az énkép és összefüggése az iskolai teljesítménnyel. In.: Mészáros A. (szerk.): Az iskola szociálpszichológiai jelenségvilága. ELTE Eötvös Kiadó, Budapest.

15. Ligeti Gy. (2005): Gyújtós-iskola, demokrácia, civilizáció. Iskolakultúra, 2005. 2. sz. 112 .

16. Neményi M. (2007): Az iskolai esélyek társadalmi meghatározottsága. Kutatási zárótanulmány.

17. Orosz, J., Szitó I. (1999): Az iskolai énkép a serdülőkorban. In: Bollókné Panyik, I. (szerk.): Gyermek, nevelés, pedagógusképzés. Trezor Kiadó, Budapest. 39-74.

18. Papp G. (1995): Tanulásban akadályozott gyermekek integrációja. In Perlusz A. (szerk.): Fogyatékos gyermekek integrált nevelése hazai kísérletek tükrében. BGGYTF, Budapest, 5-17.

19. Pető I., Nagy Z. É. (2004): Az észak-alföldi régió általános iskolái - a befogadó nevelés szempontjából 2004. (14. évf.) 4. sz. 51. old., Iskolakultúra - Társadalomtudomány.

20. Pusztai G., Torkos K. (2001): Roma gyerekkor a Partium területén. Educatio 3., 584-594.

21. Sebba, J. C. (1996): Developing Inclusive Schools (kézirat).

22. Strein, W. (1993). Advances in research on academic self-concept: Implications for school psychology. School Psychology Review, 22, 273-284.

23. Szabó É. (2003): Szociálpszichológia iskolai vezetőknek. In: Baráth T., Golnhofer, E. (szerk): Iskolavezetés és fejlesztés. Szegedi Tudományegyetem, Szeged, 1-118. 